\title{
Process optimization of fortified sweetened milk kefir
}

\author{
Kavita K Solanki and Bikash C Ghosh
}

Received: 09 May 2020 / Accepted: 31 December 2020 / Published online: 07 June 2021

(c) Indian Dairy Association (India) 2021

\begin{abstract}
Kefir is an acidic-alcoholic fermented milk product. Regular consumption of kefir is helpful in relieving intestinal disorders, reducing flatulence, and creating healthier digestive system. An attempt was made to optimise the process to produce fortified sweetened milk kefir. Kefir was prepared using kefir grains with sugar $(6,8$ and $10 \%)$, fibres (inulin, oat, and soya, each $3 \%$ ) and stabilizer $(0.1 \%$ pectin). Addition of $6 \%$ sugar showed significantly $(p<0.05)$ higher body and texture scores with no significant $(\mathrm{p}>0.05)$ difference in flavour, colour and appearance when compared to kefir made with 8 and $10 \%$ sugar. Similarly, overall acceptability was highest in kefir made with $6 \%$ sugar. Firmness in kefir was highest made with $6 \%$ sugar, followed by 8 and then $10 \%$ sugar. Among the three fibers, addition of $3 \%$ inulin showed significantly $(\mathrm{p}<0.05)$ better sensory attributes when compared to kefir added with soya and oat fibre. Acidity of inulin added kefir was lowest among soya and oat fibre added kefirs which was optimum. Kefir prepared with soya fibre showed significantly $(\mathrm{p}<0.05)$ higher acidity than other two samples. No significant $(\mathrm{p}>0.05)$ difference was observed in $\mathrm{pH}$ among all kefir samples. Firmness and consistency increased significantly $(p<0.05)$ with the addition of inulin. An acceptable quality fortified sweetened milk kefir can be prepared with $0.1 \%$ pectin, $6 \%$ sugar and $3 \%$ inulin as dietary fibre for improved health benefit.
\end{abstract}

Keywords: Colour, Dietary fibre, Flavour, Health benefit, Sweetened milk kefir

ICAR- National Dairy Research Institute, Adugodi, Bengaluru- 560 030, India

Bikash C Ghosh $(\bowtie)$

ICAR- National Dairy Research Institute, Adugodi, Bengaluru- 560 030, India

Email: ghosgoga@hotmail.com

\section{Introduction}

Kefir is a fermented milk product prepared by incubating milk with either kefir grains (a group of microorganisms held together by a polysaccharide framework i.e., Kefiran) or kefir starter culture (Satir and Guzel-Seydim, 2016). Kefir differs from other fermented milk products in a way that is not a simple consequence of the metabolic action of a single microbial species but a blended microflora i.e., $66 \%$ bacilli, $16 \%$ streptococci, and $18 \%$ yeasts (Farnworth, 2003). Enthusiasm has evolved for the development, production, and utilization of kefir since its beginning, owing to its immense therapeutic benefits on the immune system, the gastrointestinal system and the digestion of cholesterol (Tamai et al. 1996). Moreover, anti-cancer, anti-bacterial and anti-fungal properties have been exhibited in vitro, animals or human models (De Moreno de LeBlanc et al. 2007). Additionally, kefir cultures can be linked to promote food safety by restraining coliforms and several pathogens (Van Wyk et al. 2011).

As kefir has a slightly acidic taste, yeasty and tangy flavour, sweetening of kefir will make the taste milder, improve flavour and overall acceptability which will be more relished by the Indian populace. In eastern part of India, dahi is used as mistidoi/dahi by adding sweetener such as jaggery which lends a caramelized flavour and colour to the dahi. Sweetening will make the kefir a product like mistidahi. Cool sweet milk kefir will be a thirst quenching and refreshing product with prickly sensation. Sweetness of the kefir will provide an exotic enrichment to the taste buds. Yet, no attempt has been made so far to prepare sweetened milk kefir and to evaluate the microbial behaviour of kefir grains in the presence of sugar.

Milk and most milk products are devoid of dietary fibre, but there is a growing awareness among consumers about the physiological benefits of fibre fortified milk products. Dietary fibres impart some basic functional characteristics like water holding capacity, viscosity, water swelling capacity, fat binding capacity, antioxidant properties etc. (Elleuch et al. 2011) and improving sensory characteristics and shelf- life of the product. Various published reports have demonstrated that there are numerous therapeutic benefits related with the consumption of dietary fibre, including lower risk of heart diseases, diabetes, 
obesity, and a few types of malignancy (Mann and Cummings 2009). Addition of inulin has shown that it can attenuate the cholesterol in blood plasma (Roberfroid, 2005) and improves calcium, magnesium, and iron absorption (Bosscher et al. 2003). Addition of oat fibres is linked with depletion of post-prandial blood glucose and insulin responses (Wood et al. 1994), higher transport of bile acids towards lower portions of the gut and higher discharges of bile acids (Dongowski et al. 2005) or reduction of serum cholesterol levels (Hecker et al. 1998). Yogurt fortified with soya is advantageous in reducing cholesterol levels (Crouse et al. 1999), blood pressure and to alleviate indications of menopause and osteoporosis (Messina et al. 2004). To know the beneficial effects of kefir consumption, an attempt was made to optimize the process for preparation of fortified sweetened milk kefir.

\section{Materials and Methods}

\section{Raw materials and ingredients}

Fresh whole and skim milk were procured from the Experimental Dairy Plant of ICAR- National Dairy Research Institute, Bengaluru (India). Kefir grains were obtained from U.S. Food grade High methoxy pectin obtained from M/s Hi Media laboratories Pvt. Ltd. Refined crystalline cane sugar from local market, Dietary soya fibre (Fimbrim ${ }^{\circledR}$ from M/s Solae Company, U.S.), oat fibre (Vitacel ${ }^{\circledR} H F-600 \circledR$ from M/s J. Rettenmair and Sohne Gmbh, Germany) and inulin (from M/s DKSH India Pvt. Ltd., Bangalore, India) were procured.

\section{Activation of kefir grains}

Kefir grains were activated according to the technique adopted by Angulo et al. (1993). Following each incubation, straining of the fermented product was done through nylon sieve (mesh size: $1 / 20$ inch) to retrieve the kefir grains which were then washed with sterile distilled water prior to next inoculation. This process was repeated 4-5 times until the desirable kefir flavour was achieved.

\section{Preparation of fortified sweetened milk kefir}

Fresh raw milk was standardized to $3 \%$ fat, preheated at $50-60^{\circ} \mathrm{C}$ and homogenized in two stage (first stage- $2500 \mathrm{psi}$, second stage$500 \mathrm{psi}$ ) homogenizer. All the additives were added on milk basis into the milk after homogenization and before final heat treatment. During optimization process, first pectin $(0.1 \%)$ and sugar $(6,8$ and $10 \%$ ) were mixed and then added to standardized milk followed by addition of fibres (inulin, oat, and soya fibre). Milk was heated to $90-92^{\circ} \mathrm{C}$ for 10 minutes with intermittent stirring followed by cooling $\left(28-30^{\circ} \mathrm{C}\right)$ and filtration to remove any coagulated particles. Kefir grains were inoculated to the milk at a level of $4 \mathrm{~g} / \mathrm{L}$ of milk and incubated at $30^{\circ} \mathrm{C}$ for about $20-24 \mathrm{~h}$ in B.O.D incubator till the titratable acidity had reached to $1 \%$ lactic acid. The product was thoroughly stirred and sieved through nylon sieve (mesh size: 1/
20 inch). After retrieving the kefir grains, the products were then filled in polypropylene cups and kept for maturation for $24 \mathrm{~h}$ at 6 $8^{\circ} \mathrm{C}$. Thereafter, the product was stored in the refrigerator.

\section{Sensory evaluation}

Sensorial assessment of the milk kefir was carried out by an expert panel of minimum five judges to judge the kefir samples on a 9point hedonic scale ( $9=$ like extremely; $1=$ dislike extremely) at room temperature. Duo-trio tests were used to determine a candidate's ability to detect differences among similar products with different ingredients for selection of Judges.

\section{Physico-chemical analysis}

\section{pH}

The $\mathrm{pH}$ of kefir samples was measured directly by inserting the electrode into the sample followed by recording of reading.

\section{Titratable acidity}

The acidity of kefir samples was measured as per the method of AOAC947.05 (2012) for milk. The sample was well mixed, and 10 $\mathrm{g}$ of sample was taken in a beaker. Phenolphthalein indicator of 23 drops was added and titrated against $0.1 \mathrm{~N} \mathrm{NaOH}$ till the first appearance of faint pink colour. The acidity was expressed as \% lactic acid by weight.

\section{Textural analysis}

Textural properties such as firmness, consistency, index of viscosity and stickiness were determined using TA-XT Plus Texture Analyser (Stable Microsystem, UK) with $\mathrm{P} / 25$ cylindrical probe. At $6-8^{\circ} \mathrm{C}$, textural properties of kefir samples were measured using $200 \mathrm{ml}$ kefir in a $250 \mathrm{ml}$ beaker. The probe travelled at a speed of $1.0 \mathrm{~mm} / \mathrm{s}$ up to $10 \mathrm{~mm}$ distance into the kefir sample from the surface and then returned to the original position generating force-time curve. The positive peak of the curve gave firmness (Newton), the negative peak gave stickiness (Newton), the area of positive peak gave consistency (Newton-second) and the area of negative peak gave index of viscosity (Newtonsecond).

\section{Statistical analysis}

The data were subjected to analysis of variance (ANOVA) using IBM SPSS statistics 23 software. Results of triplicate trials were used for statistical analysis.

\section{Results and Discussion}

\section{Effect of sugar addition on sensory attributes of milk kefir}

All sugar (6, 8 and 10\%) added kefir samples scored higher for flavour as compared to control (Fig. 1 a). The most notable 


\section{Flavour}

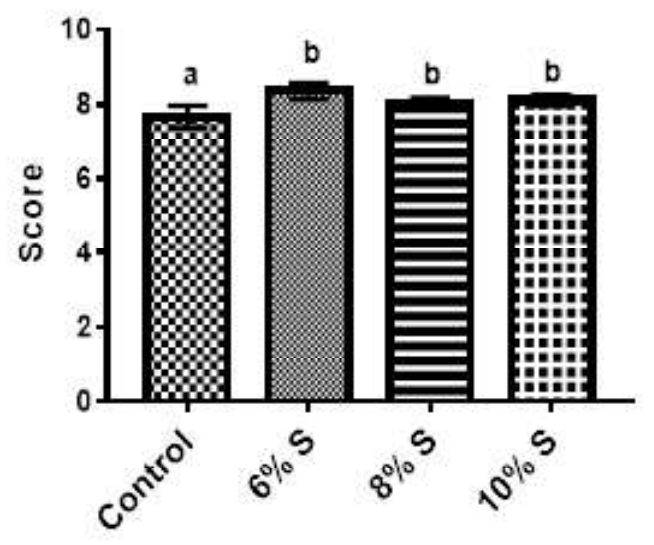

Colour and appearance

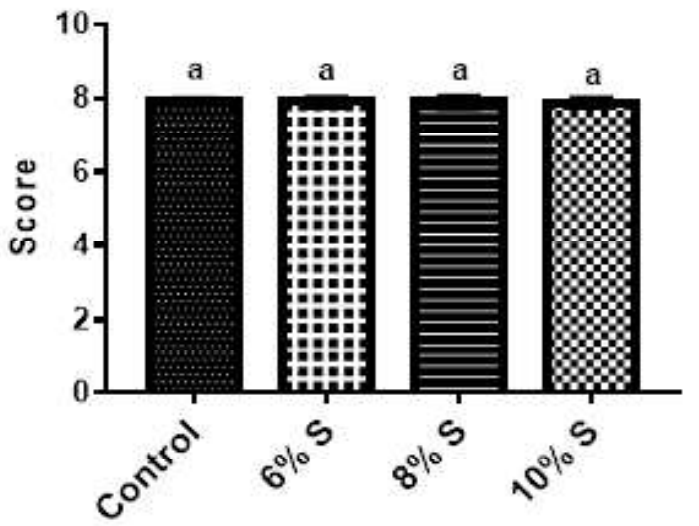

Body and texture

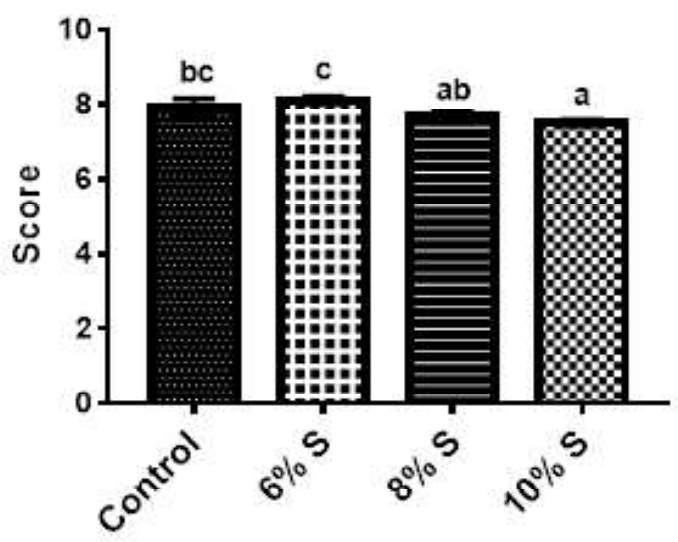

Overall acceptability

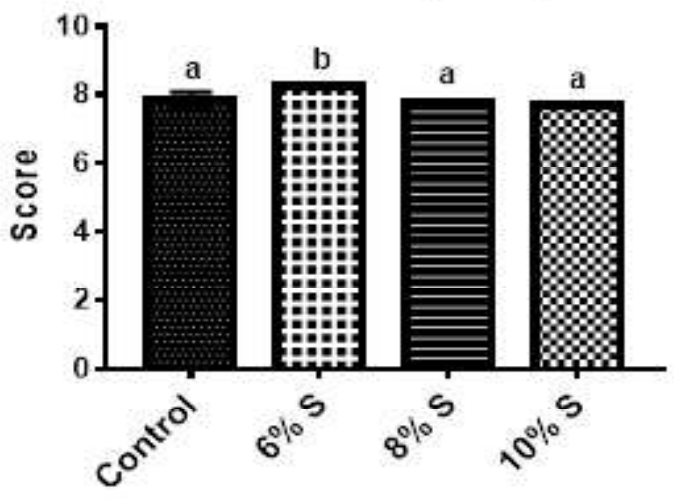

Fig. 1Effect of sugar addition on sensory attributes of milk kefir

function of sugar in food is its sweet taste. Sweet taste serves as a sensory cue for source of pleasure. Body and texture score of kefirs with $6 \%$ sugar was significantly $(\mathrm{p}<0.05)$ higher than other three kefir samples (Fig. 1 b). Sugar affected the physical characteristics of kefir to a significant degree. It provided solids which impacted the mouthfeel and texture of kefir as reported by Spillane (2006) for many fermented products. No significant $(p>0.05)$ difference was observed in colour and appearance among all kefirs (Fig. $1 \mathrm{c}$ ). Overall acceptability score was maximum for kefir with $6 \%$ sugar followed by control, 8 and $10 \%$ sugar added kefir, respectively (Fig. 1 d). Akter et al. (2010) evaluated the different levels of sugar $(8,10,12$ and $14 \%)$ on qualitative characteristics of mistidahi (Sweet Yoghurt) and found that 10 and $12 \%$ sugar levels obtained more organoleptic score than those of 8 and $14 \%$. So, the concentration of sugar affects the characteristics of the final fermented product - higher amount is detrimental to lactic acid bacteria and lower one does not change the original sour flavour. Similarly, in the present study an optimum $6 \%$ sugar produced the best kefir when compared to control, $8 \%$ and $10 \%$ sugar.

\section{Effect of sugar addition on $\mathrm{pH}$ and acidity of milk kefir}

No significant $(\mathrm{p}>0.05)$ difference in $\mathrm{pH}$ and acidity was observed between the control and 6\% sugar added kefir. Whereas kefir with 8 and $10 \%$ sugar showed significantly $(\mathrm{p}<0.05)$ lower acidity and higher $\mathrm{pH}$ than the control and kefir with $6 \%$ sugar (Table 1), making them less preferred to other kefir samples. Sugar acts as a substrate for lactic acid bacteria and yeast species in kefir grains and is responsible for development of acidity during the fermentation. The amount of acidity present depends upon the concentration of sugar and incubation time. Yeasts are recognized in playing a key role in the preparation of fermented dairy products, where they provide essential growth nutrients such as amino acids and vitamins, alter $\mathrm{pH}$, secrete ethanol, and produce $\mathrm{CO}_{2}$ (Farnworth, 2003). Hence, lower acidity was observed in 8 and $10 \%$ sugar added kefir. Ghosh and Rajorhia (1990) also found similar results in mistidahi and stated that higher concentration of sugar showed inhibitory effect in the mistidahi. The activity of the Lactobacillus cultures was greatly affected with the increase in sucrose concentration which alters morphology by elongating and distorting the cell. 
Firmness (N)

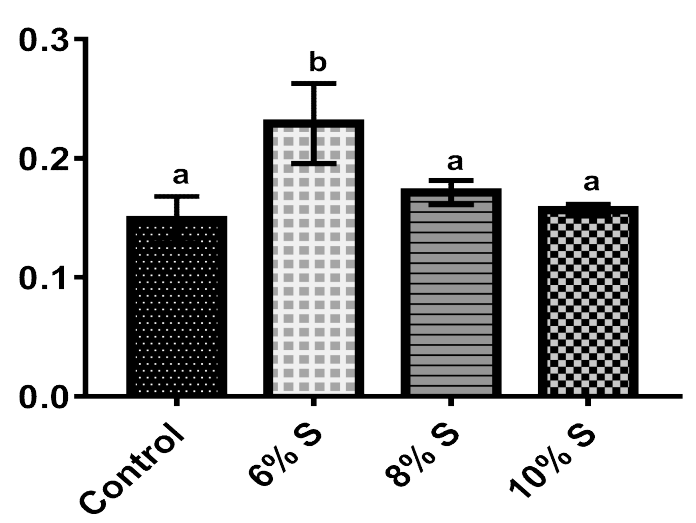

Index of viscosity (N.s)

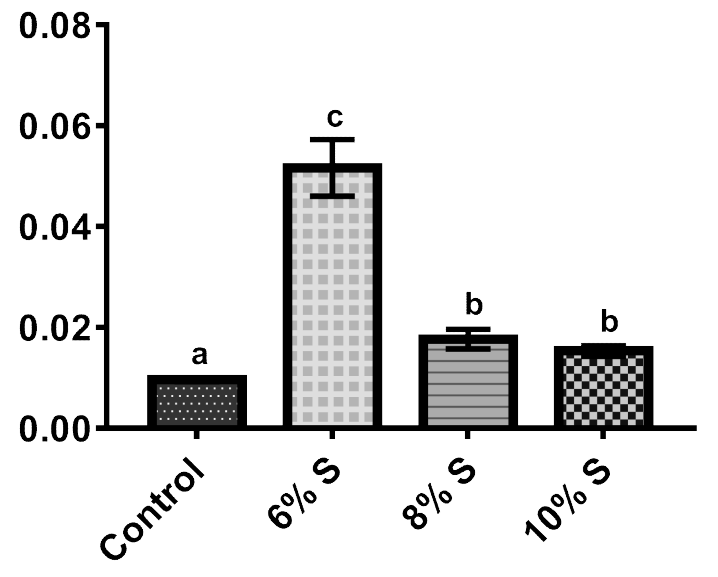

Consistency (N-s)

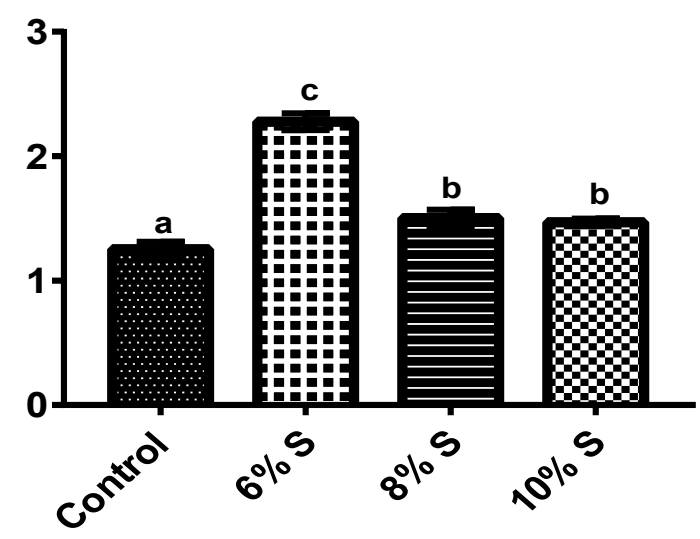

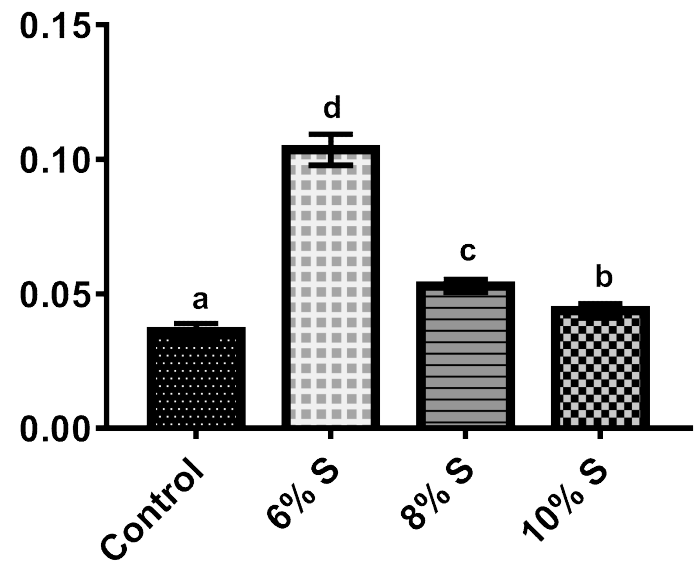

Fig. 2 Effect of sugar addition on textural properties of milk kefir

\section{Effect of sugar addition on textural properties of milk kefir}

Firmness was significantly $(\mathrm{p}<0.05)$ higher for kefir with $6 \%$ sugar as compared to other kefir samples (Fig. 2 a). Kefir with $6 \%$ sugar showed highest firmness, followed by 8 and $10 \%$ sugar added kefir and then control kefir (Fig. 2 a). Kefir with $6 \%$ sugar showed the highest consistency among all kefir samples. Kefir with 8 and $10 \%$ sugar showed significantly $(\mathrm{p}<0.05)$ higher consistency as compared to control kefir (Fig. 2 b). Similarly, kefir with $6 \%$ sugar exhibited significantly $(\mathrm{p}<0.05)$ higher index of viscosity among the four types of kefir (Fig. 2 c). Stickiness was the highest in kefir with $6 \%$ sugar, followed by with $8,10 \%$ sugar and control, respectively (Fig. 2 d). Textural properties of kefir were improved with the addition of sugar due to increase total solids content in sweetened milk kefir as compared to control. However, kefir with 8 and $10 \%$ sugar showed lower textural properties which may be due to higher $\mathrm{CO}_{2}$ production in the kefir. Whey pockets and gas holes were observed with increasing sugar content in kefir. Since kefir added with $6 \%$ sugar showed the best sensorial attributes, optimum $\mathrm{pH}$ and acidity and better textural properties, it was selected for further optimization of dietary fibre.

\section{Effect of dietary fibres incorporation on sensory attributes of sweetened milk kefir}

The effects of dietary fibre incorporation on the sensory attributes of kefir are displayed in Fig. 3. Six percent sugar was added in all samples. Control sample was added with sugar but without dietary fibre. Significantly $(\mathrm{p}<0.05)$ higher flavour was observed in inulin added kefir among four samples (Fig. 3 a). Soya fibre added kefir showed significantly $(\mathrm{p}<0.05)$ lower flavour than other kefirs (Fig. 3 a). The body and texture of kefir with inulin was the highest among all kefirs (Fig. 3 b). Inulin added kefir and control kefir showed no significant $(\mathrm{p}>0.05)$ difference in colour and appearance (Fig. 3 c). Whereas oat fibre added kefir showed significantly $(\mathrm{p}<0.05)$ inferior colour and appearance when compared to control but significantly $(\mathrm{p}<0.05)$ better than soya fibre added kefir (Fig. 3 c). Overall acceptability of inulin added 
Flavour

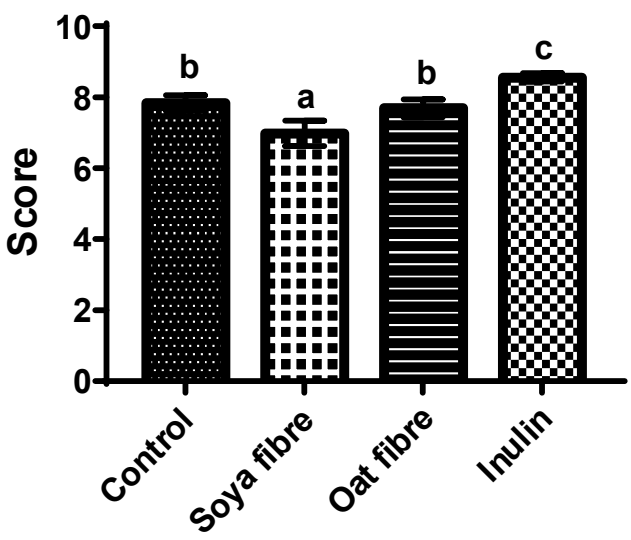

Colour and appearance

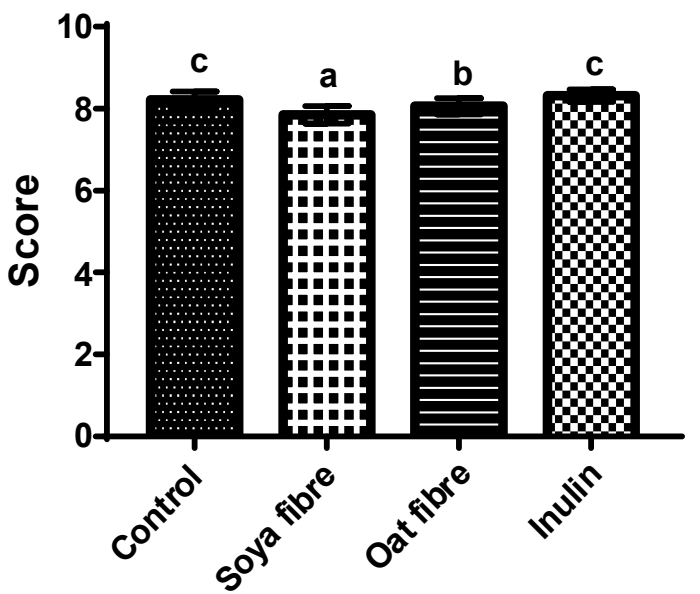

Body and texture

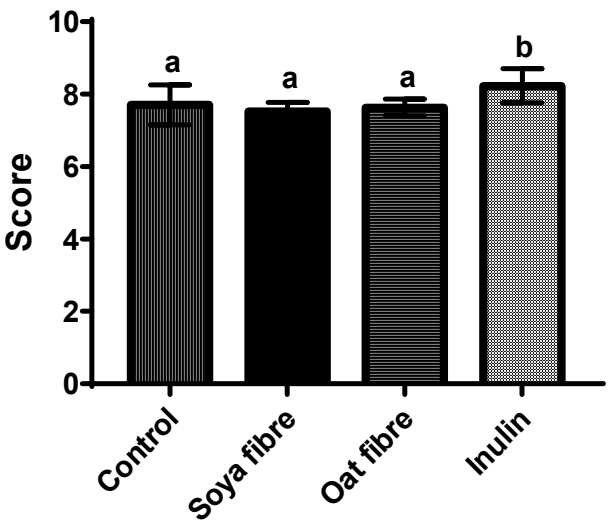

Overall acceptability

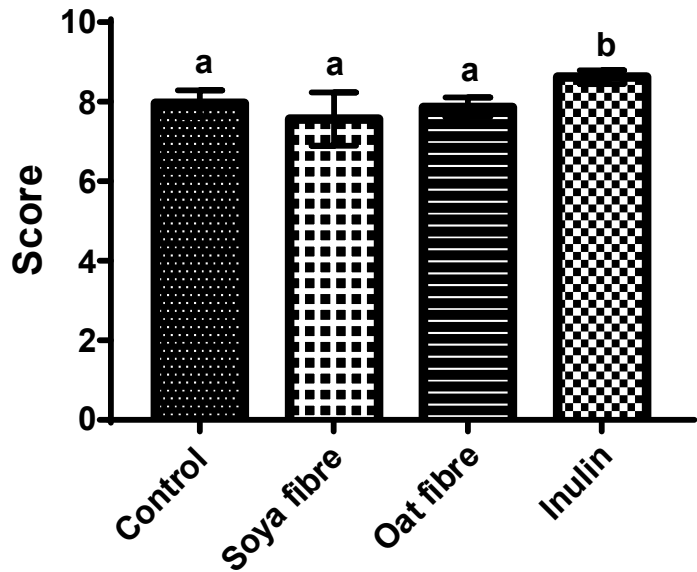

Fig. 3 Effect of dietary fibres incorporation on sensory attributes of sweetened milk kefir

Table 1 Effect of sugar addition on acidity and $\mathrm{pH}$ of milk kefir

\begin{tabular}{lllll}
\hline Attributes & Control & $6 \%$ Sugar & $8 \%$ Sugar & $10 \%$ Sugar \\
\hline Acidity & $1.13 \pm 0.01^{\mathrm{b}}$ & $1.07 \pm 0.05^{\mathrm{b}}$ & $0.98 \pm 0.02^{\mathrm{a}}$ & $0.99 \pm 0.01^{\mathrm{a}}$ \\
$\mathrm{pH}$ & $4.43 \pm 0.01^{\mathrm{a}}$ & $4.44 \pm 0.01^{\mathrm{a}}$ & $4.49 \pm 0.03^{\mathrm{b}}$ & $4.48 \pm 0.02^{\mathrm{b}}$ \\
\hline
\end{tabular}

Mean \pm S.D; means with different superscripts in a row differ significantly $(\mathrm{p}<0.05)(\mathrm{n}=3)$

kefir was maximum followed by control and then kefir added with oat and soya fibre, respectively (Fig. 3 d). The better sensory attributes of inulin added kefir might be because of additional sweetening effect of inulin which might have masked the acidic taste of kefir and improved the flavour (Allgeyer et al. 2010). No significant $(p>0.05)$ difference was found in terms of taste and consistency when inulin was added to kefir made with skim milk powder (Glibowski and Kowalska 2012). Similarly, Ertekin and Guzel- Seydim (2010) found that odour and taste of kefir samples were indifferent with or without inulin. Loss of flavour, colour and appearance in soya milk kefir fortified with soya fibre was also reported by Baú, et al. (2014). Although soya fibre is relatively soluble as compared to oat fibre, but sensory attributes were least in kefir added with soya fibre. The lower sensory attributes of kefir with oat fibre were due to settling of fibres at the bottom of container during incubation which resulted in an unacceptable appearance.

Effect of dietary fibres incorporation on $\mathrm{pH}$ and acidity of sweetened milk kefir

Soya fibre added kefir showed significantly $(\mathrm{p}<0.05)$ higher acidity as compared to other samples. No significant $(\mathrm{p}>0.05)$ difference was observed in $\mathrm{pH}$ among all types of kefir (Table 2). Typically, 
Firmness (N)
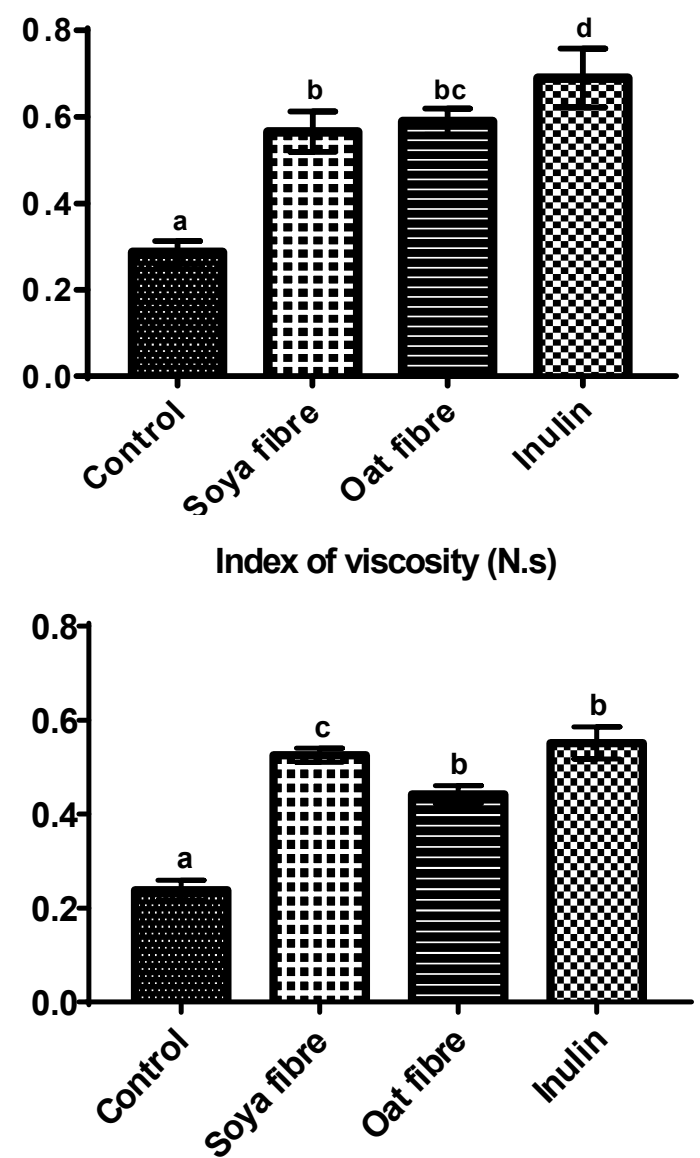

Consistency (N.s)

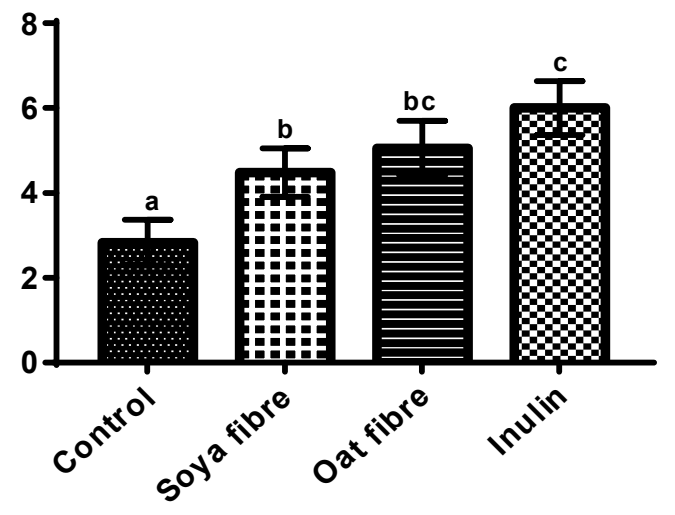

Stickiness (N)

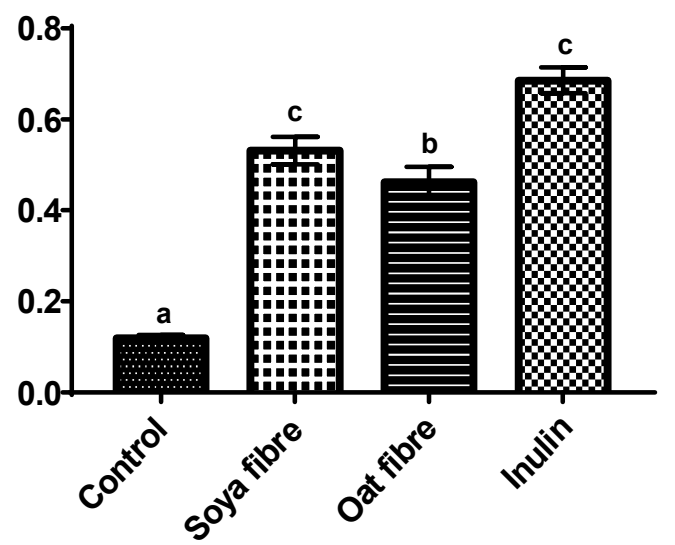

Fig. 4 Effect of dietary fibres incorporation on textural properties of sweetened milk kefir

Table 2 Effect of dietary fibres incorporation on acidity and $\mathrm{pH}$ of sweetened milk kefir

\begin{tabular}{lllll}
\hline Attributes & Control kefir $(6 \% \mathrm{~S})$ & Soya fibre & Oat fibre & Inulin \\
\hline Acidity & $1.07 \pm 0.12^{\mathrm{a}}$ & $1.21 \pm 0.03^{\mathrm{c}}$ & $1.12 \pm 0.06^{\mathrm{ab}}$ & $1.09 \pm 0.03^{\mathrm{ab}}$ \\
$\mathrm{pH}$ & $4.45 \pm 0.04^{\mathrm{a}}$ & $4.34 \pm 0.12^{\mathrm{a}}$ & $4.42 \pm 0.04^{\mathrm{a}}$ & $4.44 \pm 0.02^{\mathrm{a}}$ \\
\hline
\end{tabular}

Mean \pm S.D; means with different superscripts in a row differ significantly $(\mathrm{p}<0.05)(\mathrm{n}=3)$

$\mathrm{pH}$ of kefirs made in dairy industry ranged between $\mathrm{pH} 4.3$ and 4.4 , and similar $\mathrm{pH}$ values were observed in the present study, where addition of different fibers did not affect $\mathrm{pH}$ and acidity significantly $(p>0.05)$ except that higher acidity in soya fiber added kefir was observed. Baú et al. (2014) in the study with soya milk kefir prepared with soya fibre $(3 \% \mathrm{w} / \mathrm{w})$ showed higher acidity and lower $\mathrm{pH}$ as compared to kefir without soya fibre and they concluded that some fibre may stimulate the metabolism of the kefir grains resulting in higher acidity. Ertekin and GuzelSeydim (2010) studied the effect of $2 \%$ inulin on physicochemical properties of kefir and $\mathrm{pH}$ was found to be between 4.29 and 4.40 . They concluded that neither high performance nor native inulin did affect the $\mathrm{pH}$ changes in kefirs significantly $(\mathrm{p}>0.05)$. Although in the present study, there were no significant $(p>0.05)$ differences in $\mathrm{pH}$ and acidity of different fibre added kefirs, but kefir added with inulin showed optimum $\mathrm{pH}$ and acidity and obtained better sensorial and textural properties.

\section{Effect of dietary fibre incorporation on textural properties of sweetened milk kefir}

Firmness was significantly $(p<0.05)$ increased after addition of inulin in the preparation of kefir (Fig. 4 a). It was highest for inulin added kefir, followed by oat and soya fibre added kefir and then control kefir (Fig. 4 a). Consistency was significantly $(p<0.05)$ better in inulin added kefir (Fig. 4 b). Kefir added with soya and oat fibre also showed significantly $(\mathrm{p}<0.05)$ higher consistency than control kefir (Fig. 4 b). It was witnessed that index of viscosity of inulin added kefir was maximum among the four samples (Fig. 4 c). Similarly, stickiness of kefir was enhanced after inulin 
addition as compared to control kefir (Fig. 4 d). Soluble fibers like inulin formed viscous gel and modified the product textural properties. Sendra et al. (2010) have also reported increased firmness and viscosity in fermented milk products with the addition of different fibres. In the present study inulin added kefir showed significantly $(\mathrm{p}<0.05)$ higher textural properties as compared to control, oat and soya fibre added kefir which may be ascribed to stable gel formation being soluble fibre as compared to relatively less soluble oat and soya fibre which subsequently settled in the bottom. Moreover, the increased viscosity in inulin added kefir may be attributed due to increased total solids content and due to the higher molecular weight of inulin (Buriti et al. 2010). Increased production of polysaccharide due to the prebiotic effect of inulin must have also indirectly decreased the syneresis, increased the viscosity and firmness during the product storage (Jolly et al. 2002).

\section{Conclusions}

An attempt was made to develop fibre fortified sweetened milk kefir as a potential healthy alternative to mistidohi and yogurt. Sensory evaluation of developed sweetened milk kefir revealed that addition of $6 \%$ sugar made its taste more palatable which was liked by the taste of the Indian populace. Inulin addition of $3 \%$ improved the textural properties of sweetened kefir and contributed to its acceptance. An acceptable quality fortified sweetened milk kefir can be prepared with $0.1 \%$ pectin, $6 \%$ sugar and $3 \%$ Inulin fortification.

\section{Acknowledgments}

The first author acknowledges the receipt of fellowship from the institute of ICAR-National Dairy Research Institute (SRS) to carry out the research.

\section{References}

Akter N, Nahar A, Islam M, Al-Amin M (2010) Effects of different level of starter culture and sugar on manufacturing characteristics of MistiDahi (Sweet Yoghurt). J Bangladesh Agril Univ 8: 7933

Allgeyer LC, Miller MJ, Lee S-Y (2010) Drivers of Liking for Yogurt Drinks with Prebiotics and Probiotics. J Food Sci 75(4): S212S219.

Angulo L, Lopez E, Lema C (1993) Microflora present in kefir grains of the Galician region (North-West of Spain). J Dairy Res 60: 263

AOAC, (2012). Official methods of analysis of AOAC international, $19^{\text {th }}$ edition, Washington DC

Baú TR, Garcia S, Ida EI (2014) Evaluation of a functional soy product with addition of soy fiber and fermented with probiotic kefir culture. Braz Arch Biol Technol 57: 402-409

Bosscher D, Van Caillie-Bertrand M, Van Cauwenbergh R, Deelstra H (2003) Availabilities of calcium, iron, and zinc from dairy infant formulas is affected by soluble dietary fibers and modified starch fractions. Nutr 19: 641-645

Buriti FCA, Castro IA, Saad SMI (2010) Effects of refrigeration, freezing and replacement of milk fat by inulin and whey protein concentrate on texture profile and sensory acceptance of synbiotic guava mousses. Food Chem 123: 1190-1197
Crouse JR, Morgan T, Terry JG, Ellis J, Vitolins M, Burke GL (1999) A Randomized trial comparing the effect of casein with that of soy protein containing varying amounts of isoflavones on plasma concentrations of lipids and lipoproteins. Arch Intern Med 159(17): 2070-2076.

De Moreno de LeBlanc A, Matar C, Farnworth E, Perdigón G (2007) Study of immune cells involved in the antitumor effect of kefir in a murine breast cancer model. J Dairy Sci 90: 1920-1928

Dongowski G, Drzikova B, Senge B, Blochwitz R, Gebhardt E, Habel A (2005) Rheological behaviour of $\beta$-glucan preparations from oat products. Food Chem 93: 279-291

Elleuch M, Bedigian D, Roiseux O, Besbes S, Blecker C, Attia H (2011) Dietary fibre and fibre-rich by-products of food processing: Characterisation, technological functionality and commercial applications: A review. Food Chem 124: 411-421

Ertekin B, Guzel-Seydim ZB (2010) Effect of fat replacers on kefir quality. J Sci Food Agric 90: 543-548

Farnworth ER (2003). In: Handbook of fermented functional foods. CRC, Boca Raton, FL.

Ghosh J, Rajorhia GS (1990) Technology for production of mistidahi - A traditional fermented milk product. Indian J Dairy Sci 43: 239-246

Glibowski P, Kowalska A (2012) Rheological, texture and sensory properties of kefir with high performance and native inulin. J Food Eng 111: 299-304

Hecker KD, Meier ML, Newman RK, Newman CW (1998) Barley $\beta$ glucan is effective as a hypocholesterolaemic ingredient in foods. $\mathrm{J}$ Sci Food Agric 77: 179-183

Jolly L, Vincent SJF, Duboc P, Neeser J-R (2002) Exploiting exopolysaccharides from lactic acid bacteria. In: Lactic Acid Bacteria: Genetics, Metabolism and Applications. 367-374

Mann JI, Cummings JH (2009) Possible implications for health of the different definitions of dietary fibre. Nutr Metab Cardiovasc Dis 19: 226-229

Messina E, De Angelis L, Frati G, Morrone S, Chimenti S, Fiordaliso F, Vivarelli E (2004) Isolation and expansion of adult cardiac stem cells from human and murine heart. Circ Res 95: 911-921

Roberfroid MB (2005) Introducing inulin-type fructans. Br J Nutr 93: 1325.

Satir G, Guzel-Seydim ZB (2016) How kefir fermentation can affect product composition? Small Ruminant Res 134: 1-7

Sendra E, Kuri V, Fernández-López J, Sayas-Barberá E, Navarro C, PérezAlvarez JA (2010) Viscoelastic properties of orange fiber enriched yogurt as a function of fiber dose, size and thermal treatment. LWT - Food Sci Technol 43: 708-714

Spillane WJ (2006) Optimising sweet taste in foods, CRC Press, Boca Raton, FL, p. 415

Tamai Y, Yoshimitsu N, Watanabe Y, Kuwabara Y, Nagai S (1996) Effects of milk fermented by culturing with various lactic acid bacteria and a yeast on serum cholesterol level in rats. J Ferment Bioeng 81: $181-182$

Van Wyk J, Witthuhn RC, Britz TJ (2011) Optimisation of vitamin B12 and folate production by Propionibacterium freudenreichii strains in kefir. Int Dairy J 21: 69-74

Wood P, Braaten JT, Scott FW, Riedel KD, Wolynetz MS, Collins MW (1994) Effect of dose and modification of viscous properties of oat gum on plasma glucose and insulin following an oral glucose load. $\mathrm{Br}$ J Nutr 72: 731-35 